\title{
The Renal Handling of Low Molecular Weight Proteins
}

\author{
II. DISORDERS OF SERUM PROTEIN \\ CATABOLISM IN PATIENTS WITH TUBULAR PROTEINURIA, \\ THE NEPHROTIC SYNDROME, OR UREMIA
}

\author{
Thomas A. Waldmann, Warken Strober, and R. Peter Mogielnicki \\ From the Immunophysiology Section of the Metabolism Branch, National Cancer \\ Institute, National Institutes of Health, Bethesda, Maryland 20014
}

A в S T RAC T The present study was directed toward determining the role of the kidney in the metabolism of various classes of serum proteins and to define the urinary protein excretion patterns and the pathogenesis of disorders of protein metabolism in patients with proteinuria. To this end, the metabolic fates of a small protein, $\lambda-\mathrm{L}$ chain ( $\mathrm{mol}$ wt 44,000 ), and a protein of intermediate size, IgG (mol wt 160,000), were studied in controls and patients with renal disease. Controls metabolized $0.28 \% / \mathrm{hr}$ of circulating IgG and $22.3 \% / \mathrm{hr}$ of circulating $\lambda-\mathrm{L}$ chain. All the IgG and $99 \%$ of the $\lambda$-L chain was catabolized with the remaining $\lambda$-L chain lost intact into the urine. The kidney was shown to be the major site of catabolism for small serum proteins. Three distinct disorders of protein metabolism were noted in patients with renal tubular disease and tubular proteinuria, glomerular disease (the nephrotic syndrome), and disease involving the entire nephrons (uremia), respectively. Patients with renal tubular disease had a 50 fold increase in the daily urinary excretion of $15-40,000$ molecular weight proteins such as lysozyme and $\lambda-L$ chains. Serum IgG and $\lambda-L$ chain survivals were normal; however, the fraction of the over-all $\lambda-\mathrm{L}$ chain metabolism accounted for by proteinuria was increased 40 -fold whereas endogenous catabolism was correspondingly decreased. Thus, tubular proteinuria results from a failure of proximal tubular uptake and catabolism of small proteins that are normally filtered through the glomerulus. Patients with the nephrotic syndrome had a slight increase in $\lambda-\mathrm{L}$ chain survival whereas IgG survival was decreased and the fraction of IgG lost in the urine was

An abstract of this work appeared in J. Clin. Invest. 1970. 49: 99a. (Abstr.)

Received for publication 28 December 1971 and in revised form 13 March 1972. markedly increased. Here, abnormal glomerular permeability to proteins of intermediate size is the basic abnormality. Patients with uremia had a normal IgG survival but a four to 10 -fold prolongation of $\lambda$ - $\mathrm{L}$ chain survival due to loss of entire nephrons, the major site of metabolism of these proteins. This results in an increase (up to 10 -fold) in the serum concentration of $\lambda$ - $L$ chain, lysozyme, and other small biologically active proteins, a phenomenon that may be of importance in causing some of the manifestations of the uremic syndrome.

\section{INTRODUCTION}

The relationship of normal renal function to the metabolism of serum proteins is reflected in the fact that proteinuria and abnormalities of serum protein concentration accompany most forms of renal disease. In recent years this role of the kidney in protein metabolism has been clarified with the use of analytical techniques for the quantitation of proteins in biological fluids. Such techniques have led to the concept that there are two main forms of proteinuria, one associated with glomerular damage, glomerular proteinuria, and the other associated with disorders of the convoluted tubule of the kidney, tubular proteinuria. In glomerular proteinuria large quantities of proteins of intermediate molecular size such as albumin ( $m o l ~ w t ~ 68,000)$, transferrin ( $\mathrm{mol} \mathrm{wt} \mathrm{90,000),}$ and, to a lesser extent, IgG (mol wt 160,000) appear in the urine. In tubular proteinuria the total urinary protein loss is usually much less than in glomerular proteinuria and the proteins present in greatest abundance in the urine are a heterogeneous group of proteins with relatively low molecular weights (mol wt $10-50,000$ ) including serum enzymes, immunoglobulin light chains, and small protein hormones (1-8). As the name implies, 
tubular proteinuria is observed in a number of conditions showing acquired or hereditary abnormalities of renal tubular function. Examples include cadmium poisoning (9), Wilson's disease (10), hypokalemic nephropathy (11), acute tubular necrosis (12), renal allograft rejection (13), and the Fanconi syndrome (1).

A second technique that has been applied to the study of the role of the kidney in protein homeostasis is the use of radiolabeled proteins in metabolic turnover studies. Such studies provide a quantitative description of the various pathways of metabolism and excretion for individual protein components. They have been used to determine the role of the kidney in albumin metabolism in both normal individuals and those with glomerular disease (14-18). In addition, metabolic turnover studies have been used to show that the kidney is a major site of catabolism of low molecular weight serum proteins (19-24).

In the present study analytical techniques and turnover studies with radiolabeled proteins were used in concert to shed additional light on the pathogenesis of abnormalities of serum and urinary protein levels in patients with different forms of renal disease. To this end the metabolic fates of a small serum protein, $\lambda$-L chain ( $\mathrm{mol} \mathrm{wt} \mathrm{44,000)}$ and a protein of intermediate size, IgG ( $\mathrm{mol}$ wt 160,000 ), were studied in control individuals as well as in patients with glomerular damage and the nephrotic syndrome, patients with renal tubular disease, and patients with nephron loss and uremia.

\section{METHODS}

Patient material. 45 turnover studies were performed with purified lambda $(\lambda) \mathrm{L}$ chain dimers ( $\mathrm{mol}$ wt 44,000) or IgG (mol wt 160,000$)$ in patients with proximal renal tubular disease, the nephrotic syndrome or uremia and in control individuals. The five patients with tubular proteinuria included two adults with familial Fanconi syndrome and three children with cystinosis and the Fanconi syndrome. Each of these patients had aminoaciduria, glycosuria, and phosphaturia. The two patients with the adult Fanconi syndrome and one of the children with cystinosis had normal blood urea nitrogen and creatinine clearance values. The remaining two patients with cystinosis had blood urea nitrogen values of 42 and $50 \mathrm{mg} / 100 \mathrm{ml}$ and reduced creatinine clearance values. The six patients with glomerular damage and the nephrotic syndrome included four patients with idiopathic nephrosis, one with amyloidosis and one with Sjögren's syndrome. Each of these patients excreted from 5 to $15 \mathrm{~g}$ of protein in the urine per day and had hypoalbuminemia, hypogammaglobulinemia, and hypercholesterolemia. The six patients with uremia had end-stage kidney disease; blood urea nitrogen values of patients in this group ranged from 60 to $228 \mathrm{mg} / 100 \mathrm{ml}$. The controls for the IgG turnover studies were normal volunteers over the age of 21. The controls for the $L$ chain turnovers were patients with neuromuscular diseases including myotonic dystrophy and amyotrophic lateral sclerosis. Each of these individuals had a normal blood urea nitrogen and creatinine clearance value.
The serum and urine of additional patients were obtained for studies of protein excretion patterns and serum lysozyme concentrations. This group included eight patients with proximal renal tubular disease, six patients with the nephrotic syndrome, and 21 patients with uremia and endstage kidney disease.

Mode of collection and concentration of the urine. In order to determine the pattern of urinary protein excretion and the $24-\mathrm{hr}$ excretion rate of various specific proteins, urine was collected in 24-hr lots without addition of preservatives and stored at $-20^{\circ} \mathrm{C}$ until used. Before analysis urine was first clarified by centrifugation for $10 \mathrm{~min}$ at $3000 \mathrm{rpm}$ at $4^{\circ} \mathrm{C}$. The urine was then concentrated to a volume of $30-40 \mathrm{ml}$ by ultrafiltration using a Diaflo ultrafiltration apparatus ${ }^{1}$ (containing a $1000 \mathrm{~mol}$ wt cut-off, UM-2, ultrafilter). In a final concentration step the urine was reduced to a volume of $2-4 \mathrm{ml}$ by placing the urine in an $8 / 32$ Visking dialysis tube and then immersing the latter in dry, cross-linked dextran (Sephadex G-200). The exact degree of concentration achieved by these procedures was determined by adding a known quantity of ${ }^{125} \mathrm{I}$ labeled $\lambda$-type Bence Jones protein to the urine at the start of the manipulations and then determining the extent to which the labeled material was concentrated by comparing counts per milliliter in pre- and postconcentration samples of urine.

Determination of urine protein excretion patterns. (a) Urinary electrophoresis. The concentrated urine specimens were subjected to analytical polyacrylamide disc gel electrophoresis using a $7.5 \%$ alkaline polyacrylamide gel according to the method of Davis (25). In addition, polyacrylamide gel electrophoresis was also performed in the presence of the anionic detergent sodium dodecyl sulfate (SDS) ${ }^{2}$ according to the method of Shapiro, Vinuela, and Maizel (26).

(b) 24-hr excretion rates of various proteins. The concentration of total protein and specific protein components were determined in concentrated urine specimens and converted to $24-\mathrm{hr}$ excretion rates using the $24 \mathrm{hr}$ urine volume and the degree of concentration determined as discussed above. The total protein concentration of the urine was determined by the Biuret technique of Gornall, Bardawill, and David (27). The concentration of lysozyme in the urine and serum was determined by the lysoplate assay method of Osserman and Lawler (28).

The $\lambda-\mathrm{L}$ chain concentration in the urine was determined by a modification of the solid phase radioimmunoassay technique of Mann, Granger, and Fahey (29). The ${ }^{125} \mathrm{I}-$ labeled $\lambda-\mathrm{L}$ chain used in the radioimmunoassay procedure was a $\lambda-\mathrm{L}$ chain dimer (Bence Jones protein) labeled by a modification of the chloramine- $T$ method of Hunter and Greenwood (30). The anti $\lambda-\mathrm{L}$ chain antibody used reacted only with free $\lambda-L$ chain and not with $L$ chain combined with $\mathrm{H}$ chain in whole immunoglobulins. Such an antiserum was prepared by absorbing an antiserum made in sheep against free $\lambda$-L chain with chromatographically pure IgG; the resultant antiserum reacted in immunoelectrophoresis and in Ouchterlony analysis with determinants on the free $\lambda-\mathrm{L}$ chain but not with $\operatorname{IgG}, \operatorname{IgA}, \operatorname{Ig} M$, or concentrated urine from normal and agammaglobulinemic patients. In addition, whole IgG was 500 times less effective than $\lambda-\mathrm{L}$ chain (on a molar basis) in inhibiting precipitation of $\lambda-\mathrm{L}$ chain by this antibody in the radioimmunoassay.

For the urines with relatively high $\lambda-L$ chain concentra-

\footnotetext{
${ }^{1}$ Amicon Corp., Lexington, Mass.

2 Abbreviations used in this paper: EV, extravascular; IV, intravascular; SDS, sodium dodecyl sulfate.
} 
tions a supplementary assay technique, the radial diffusion method of Mancini, Carbonara, and Heremans (31), was employed. The two techniques gave equivalent results.

Preparations of radioiodinated proteins for turnover studies. IgG was prepared from normal serum by DEAE cellulose chromatography. The $\lambda-\mathrm{L}$ chain for turnover studies was prepared from the urine of a patient excreting $35 \mathrm{mg}$ of $\lambda$-Bence Jones protein per milliliter using a technique previously described (19).

The IgG and $\lambda-\mathrm{L}$ chain protein used for the turnover studies were shown to be free of contaminating proteins by double diffusion in agar and immunoelectrophoresis using an antiserum to whole human serum as well as specific antisera to each of the major classes of immunoglobulin and to $\lambda$ - and $x-\mathrm{L}$ chains. Purified IgG and $\lambda-\mathrm{L}$ chains were iodinated by the iodine monochloride method of McFarlane (32) using ${ }^{131} \mathrm{I}$. The final products contained less than 1 mole of iodine per mole of protein and were $99 \%$ precipitable with $10 \%$ trichloroacetic acid. The labeled $\lambda-\mathrm{L}$ chain was examined by analytical ultracentrifugation and was shown to have a sedimentation constant of $3.7 \mathrm{~S}$ and have a calculated molecular weight of 44,000 . Thus, the purified labeled $\lambda$-L chain was in the dimeric form.

Experimental protocol. All patients were studied while hospitalized on a balance ward. They were given $0.5 \mathrm{ml}$ of a saturated solution of potassium iodide every $8 \mathrm{hr}$ to inhibit thyroidal uptake of radioiodine. In studies of IgG metabolism, approximately $0.2 \mathrm{mg}$ of radioiodinated IgG containing $25 \mu \mathrm{Ci}$ of ${ }^{181} \mathrm{I}$ was administered intravenously from a calibrated syringe. A plasma sample was collected
$10 \mathrm{~min}$ after injection and then daily for the remaining 21 days of the study. Urine was collected in 24-hr lots for each day during this period. In studies of $\lambda$ - $\mathrm{L}$ chain metabolism, $25 \mu \mathrm{Ci}$ of ${ }^{181} \mathrm{I}$ labeled $\lambda$-L chain and $25 \mu \mathrm{Ci}$ of ${ }^{125} \mathrm{I}-$ labeled sodium iodide were administered intravenously at the same time. The iodide- ${ }^{-25} \mathrm{I}$ was used to determine the parameters of iodide metabolism as described below. Serum samples were collected at 10 and $20 \mathrm{~min}, 1,2,3,5,11$, 15 , and $24 \mathrm{hr}$ and then daily throughout the study. Urine was collected in 3-hr lots during the first $24 \mathrm{hr}$ of study and then in 12-hr lots until the study was terminated.

Measurement of radioactivity. In the $\mathrm{L}$ chain turnover studies total and nonprotein-bound ${ }^{181} \mathrm{I}$ and ${ }^{125} \mathrm{I}$ radioactivities were determined on all serum and urine samples. Proteinbound radioactivity values for the serum and urine were calculated from the difference between the total and nonprotein-bound ${ }^{131} \mathrm{I}$ radioactivity values as described previously (19) with the exception that $10 \%$ trichloracetic acid rather than perchloric acid was used to precipitate proteins. Samples were counted in an automatic gamma-ray well scintillation counter with appropriate standards to a counting accuracy of $\pm 3 \%$.

Whole body counts were obtained on six of the patients that received ${ }^{181} \mathrm{I}$-labeled $\lambda-\mathrm{L}$ chains. These patients were counted daily in a whole body radioactivity counter by methods previously described (33).

Data analysis. Plasma volumes were obtained by the method of isotope dilution. IgG pool size and the fraction of the IV IgG pool metabolized per day were determined according to the method of Nosslin (34). IgG synthetic

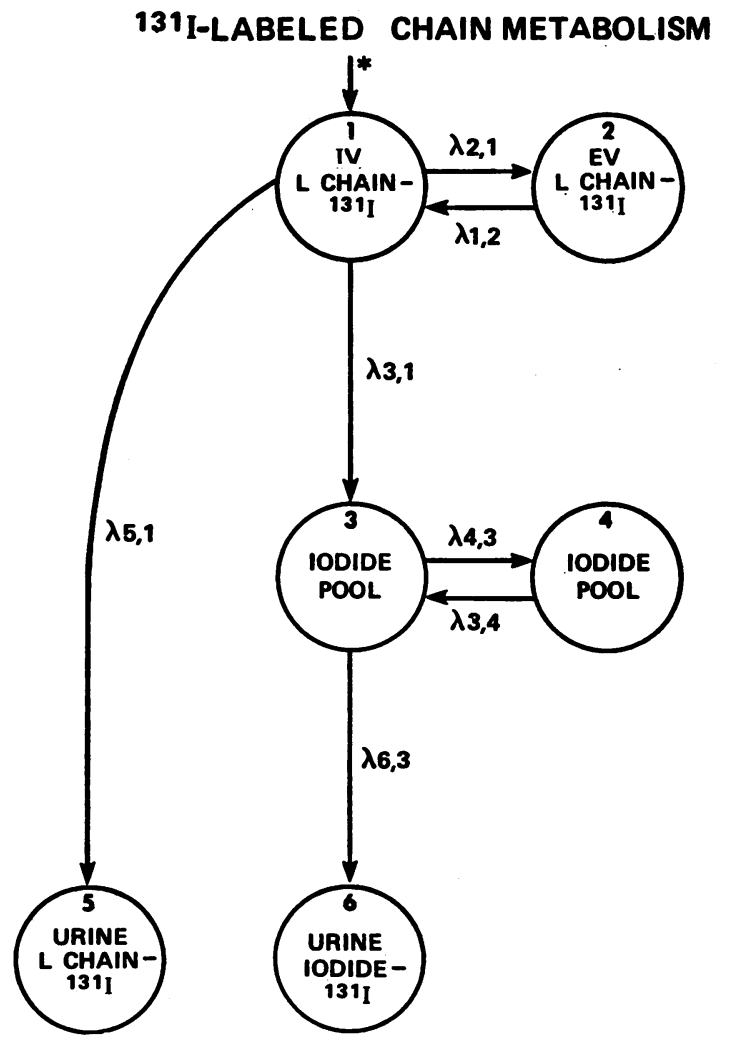

IODIDE-125I METABOLISM

FIGURE 1 Kinetic model of $\lambda$-L chain- ${ }^{131} \mathrm{I}$ and iodide- ${ }^{125} \mathrm{I}$ metabolism. See Methods section for explanation. 
rates were calculated from the product of the intravascular (IV) IgG pool size and the fractional metabolic rate.

$\lambda-\mathrm{L}$ chain turnover data were used to calculate the following metabolic parameters: the fractional proteinuric rate (the fraction of the IV pool of $\lambda-\mathrm{L}$ chain lost per hour into the urine as intact protein), the fractional catabolic rate (the fraction of the IV pool of $\lambda-\mathrm{L}$ chain lost per hour as a result of endogenous catabolism to amino acids), and the fractional metabolic or fractional disappearance rate (the fraction of the IV pool of $\lambda-\mathrm{L}$ chain lost per hour by all mechanisms, i.e., by proteinuria and endogenous catabolism). In addition, the $\lambda-\mathrm{L}$ chain turnover data were used to define the circulating and whole body pool sizes of $\lambda-L$ chains and the rate of $\lambda-\mathrm{L}$ chain synthesis.

These metabolic parameters were derived from the data using the simulation, analysis, and modeling (SAAM) computer program of Berman and Weiss $(35,36)$. Details of the program and of the data fitting techniques embodied in it have been previously published $(35-37)$. The great advantage of this method is that it allows one to use all of the experimentally obtained data simultaneously in the calculation of individual metabolic parameters. This feature is of special importance in the analysis of $\lambda-\mathrm{L}$ chain kinetics since the rate of catabolism of this protein is rapid relative to the rate of urinary excretion of the free radioiodide label released upon degradation of labeled protein.

A diagram of the compartmental model which was used in the calculation of metabolic parameters in these experiments is given in Fig. 1. It is seen that the model consists of protein and iodide pools (compartments) and intercompartmental transfer constants ( $\lambda$ 's) representing the fractional rates of transfer between the compartments. Compartment 1 represents the serum $\lambda-\mathrm{L}$ chain pool, compartment 2 represents the extravascular (EV) $\lambda-\mathrm{L}$ chain pool, compartments $\hat{i}$ and 4 represent body radioiodide pools, compartment 5 represents the cumulative protein-bound radioactivity excreted into the urine, and compartment six represents the cumulative free (non-protein-bound) radioiodide excretion into the urine.

$\lambda_{3,1}$ represents the fractional rate of transfer of label from its bound form on $\lambda-\mathrm{L}$ chain to free iodide, and therefore $\lambda_{3,1}$ is the fractional catabolic rate of $\lambda-\mathrm{L}$ chain. Similarly, $\lambda_{5,1}$ represents the fractional rate of transfer of intact labeled $\lambda-\mathrm{L}$ chain from the IV pool to the urine and thus represents the fractional proteinuric rate.

Experimental data, i.e., curves describing the die-away and accumulation of label in various compartments were available for compartments $1,3,5$, and 6 . In addition, since each patient studied was given a simultaneous injection of ${ }^{125} \mathrm{I}$ into compartment 7 , data were also available for compartment 7 , the iodide ${ }^{-25} \mathrm{I}$ radioactivity in the plasma and compartment 9, iodide- ${ }^{125} \mathrm{I}$ radioactivity in the urine. The iodide ( $\left.{ }^{20} \mathrm{I}\right)$ data was utilized in the computer for the calculation of the iodide excretion rate $\left(\lambda_{\theta, 7}\right)$ and the intercompartmental transfer constants for iodide $\left(\lambda_{8,7}\right.$ and $\left.\lambda_{7,8}\right)$. These constants also govern the movement of iodide label released as a result of $\lambda-\mathrm{L}$ chain metabolism ( ${ }^{131} \mathrm{I}$ label) and were therefore inserted into the model of $\lambda-\mathrm{L}$ chain metabolism; in other words, $\lambda_{8,7}, \lambda_{7,8}$, and $\lambda_{8,7}$, which were calculated directly from the iodide- ${ }^{125} \mathrm{I}$ data were used to provide fixed values for $\lambda_{4,3}, \lambda_{3,4}$, and $\lambda_{8,3}$.

The above data was sufficient to compute the desired metabolic parameters $\lambda_{3,1}$ and $\lambda_{5,1}$. We, however, added two additional constraints on the system derived from two other types of experimental data which further improved the reliability of the calculated $\lambda_{3,1}, \lambda_{5,1}$ values. Firstly, we re- quired that the die-away of label in the whole body, i.e., the sum of the compartments $1,2,3,4$, conform to the actual measured die-away of label in the patient as determined directly with the whole body counter. Secondly, we required that the ratio of the fractional catabolic rate to the fractional proteinuric rate (i.e., $\lambda_{3,1} / \lambda_{5,1}$ ) conform to the actual measurement of this ratio by a modification of the method used by Gitlin, Janeway, and Farr (14). In this method, the ratio is determined from the ratio of the total nonprecipitable urinary counts to the total precipitable urinary counts ( ${ }^{131} \mathrm{I}$ counts) excreted during the entire study period, that is, until there was negligible radioactivity left in the body.

The serum $\lambda-\mathrm{L}$ chain concentration could not be directly determined whereas the $24 \mathrm{hr}$ urinary excretion of $\lambda-\mathrm{L}$ chain could be directly determined by the immunological techniques discussed above. Therefore, the total circulating $\lambda-\mathrm{L}$ chain pool was calculated from the following relationship: total circulating $\lambda-\mathrm{L}$ chain protein pool $=$ hourly urinary $\lambda-\mathrm{L}$ chain excretion/hourly fractional proteinuric rate. The steady-state synthetic rate of $\lambda$ - $L$ chain was determined from the product of the fraction of the circulating $\lambda-\mathrm{L}$ chain pool metabolized per day $\left(\lambda_{5,1}+\lambda_{3,1}\right)$ and total circulating $\lambda-\mathrm{L}$ chain pool. The serum $\lambda-\mathrm{L}$ chain concentration was determined from the ratio of the total circulating $\lambda-\mathrm{L}$ chain pool and the plasma volume.

\section{RESULTS}

Protein excretion patterns in various renal disease states. The urinary protein excretion patterns of patients with various categories of renal disease including patients with renal tubular disorders, patients with diseases involving the glomerulus, and patients with endstage renal disease and uremia were studied. In the patients with renal diseases that primarily affected renal tubular function, i.e., two patients with familial adult Fanconi syndrome and 11 patients with early cystinosis, there was a moderate proteinuria of $170-820 \mathrm{mg}$ of protein daily. The proteins excreted were distributed in a characteristic pattern on alkaline acrylamide gel electrophoresis that was easily distinguishable from the pattern of proteinuria of glamerular origin (Fig. 2). The patients with renal tubular disorders had a relatively minor albumin band but had, in addition, strikingly prominent $\alpha$ - and pre- $\beta$-bands. An even more characteristic pattern of proteinuria was obtained when the urinary protein was subjected to polyacrylamide gel electrophoresis in the presence of the anionic detergent SDS. This material minimizes the native charge differences among proteins by the formation of protein-SDS complexes so that the migration of proteins into the gel is determined solely by their molecular weight (26). As shown in Fig. 3 the majority of proteins excreted by patients with tubular disease have bands of migration that move more rapidly in the gel than does albumin. Using reference proteins with known molecular weights it was shown that the major rapidly migrating bands have molecular weights ranging from 12 to 45,000 . 
These electrophoretic patterns corresponded well with measurements of excretion rates of representative proteins in patients with tubular disease. Thus, there was no significant excretion of very large serum proteins such as IgM into the urine and only a moderate increase in the urinary excretion of intermediate size proteins such as albumin (mean excretion: $117 \mathrm{mg} / 24 \mathrm{hr} ; 25.4 \%$ of total urinary protein) and IgG (mean excretion: 18 $\mathrm{mg} / 24 \mathrm{hr} ; 3.9 \%$ of total urinary protein). On the other hand, there were very high urinary excretion rates for the representative low molecular weight proteins studied. The mean daily urinary excretion of lysozyme (mol wt 17,000 ) of the 11 patients with cystinosis and the two patients with the familial Fanconi syndrome was $50.2 \pm 31$ $\mathrm{mg}$ /day compared with the $0.6 \pm 0.4 \mathrm{mg} /$ day in controls. Similarly these patients excreted $44.2 \pm 23 \mathrm{mg} /$ day (3.25 $\mathrm{mg} / \mathrm{kg}$ per day) of free $\lambda-\mathrm{L}$ chain dimers (mol wt 44,000 ) into the urine daily compared with $2.3 \pm 1.1 \mathrm{mg} /$ day $(0.04 \mathrm{mg} / \mathrm{kg}$ per day) in control individuals (Fig. 4).

A contrasting pattern of urinary protein excretion was observed in patients with renal diseases that primarily affected the glomerulus. In the first place, these patients excreted much greater quantities of protein into the urine (4.0-18.2 $\mathrm{g} / \mathrm{day})$ than did patients with tubular disease. Secondly, the acrylamide gel patterns of the urinary protein differed in that two intermediate size proteins, albumin and transferrin, were the chief protein bands seen and the multiplicity of prealbumin, $\alpha$ - and $\beta$-region bands were notably absent (Fig. 2). Moreover, on SDS

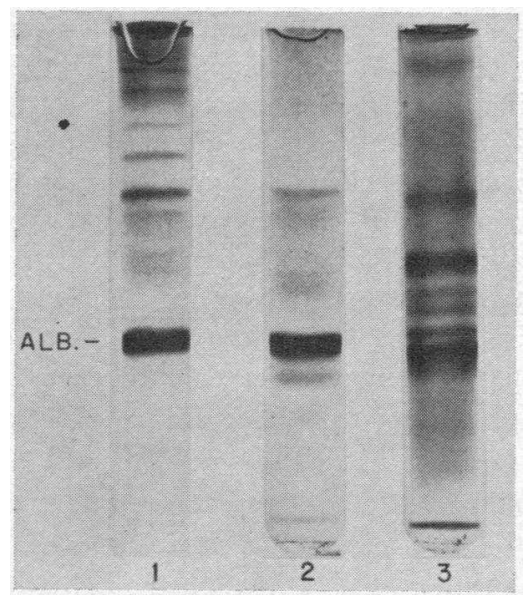

Figure 2 Alkaline acrylamide gel electrophoresis of normal serum and urine from representative patients: (1) normal serum, (2) urine from a patient with the nephrotic syndrome and glomerular damage, and (3) urine from a patient with cystinosis and renal tubular disease. Albumin and transferrin were the chief bands seen in urine from the patient with the nephrotic syndrome. The patients with renal tubular diseases had, in addition, prominent prealbu$\min , \alpha$ - and pre- $\beta$-bands.

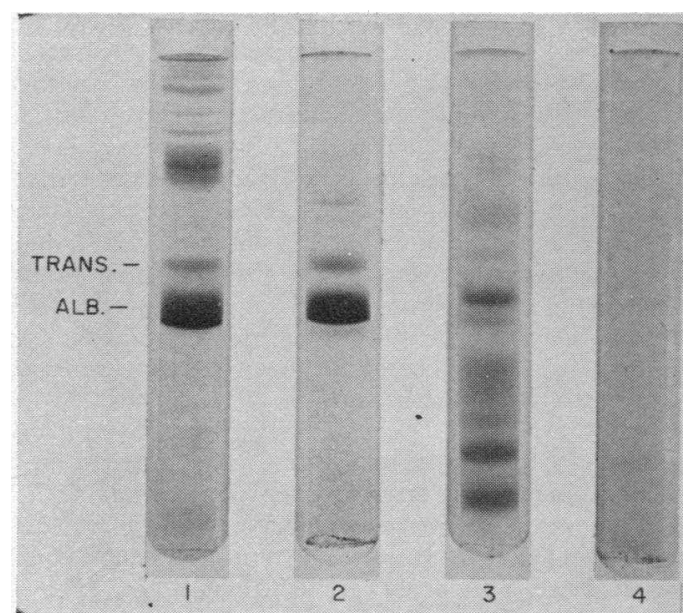

Figure 3 Sodium dodecyl sulfate acrylamide gel electrophoresis of: (1) normal serum, (2) urine from a patient with the nephrotic syndrome, (3) urine from a patient with the adult Fanconi syndrome, and renal tubular disease, and (4) urine from a normal individual. The migration of proteins into the gel is determined by their molecular size. The predominating proteins in the patients with the nephrotic syndrome ranged in molecular weight from 60 to 160,000 . In contrast, the majority of proteins excreted by the patients with tubular disease had bands of migration that moye more rapidly into the gel than does albumin. These proteins were shown to have molecular weights ranging from 12 to 45,000 .

polyacrylamide gel electrophoresis the predominating proteins associated with the nephrotic syndrome ranged in molecular weight from 60 to 200,000 and there was little or no protein in the region where proteins of less than 45,000 mol wt migrate (Fig. 3). In these patients, albumin was the predominant protein excreted, accounting for $73-86 \%$ of the total urinary protein. Other intermediate size proteins including transferrin, IgG, and IgA were excreted in significant amounts whereas the very large serum proteins such as $\operatorname{IgM}$ were still not present in the urine. The urinary excretion rate of a typical low molecular weight protein, lysozyme, was normal and that of $\lambda-\mathrm{L}$ chain was only slightly increased to $0.3 \mathrm{mg} / \mathrm{kg}$ per $24 \mathrm{hr}$ (Fig. 4). Acrylamide gel and urinary excretion patterns of patients with uremia and end-stage renal disease reflected both tubular and glomerular disease in that both low molecular weight and intermediate molecular weight proteins were excreted in excessive amounts. Nevertheless such patients with chronic uremia could be clearly distinguished from other patients with renal disease in that they had marked elevation of the serum concentration of low molecular weight proteins (Fig. 5). Thus, the 27 patients with uremia and blood urea nitrogen levels greater than 60 $\mathrm{mg} / 100 \mathrm{ml}$ had a mean serum lysozyme concentration of $71.8 \pm 25 \mu \mathrm{g} / \mathrm{ml}$; these levels were approximately 10 -fold 
greater than that of normal individuals (mean: $6.5 \pm 2$ $\mu \mathrm{g} / \mathrm{ml}$ ) patients with isolated tubular disease (mean: $8.3 \pm 2$ ) or patients with glomerular disease without significant blood urea nitrogen elevations (mean: 7.2 \pm 2 ).

Thus, distinctive urinary and serum protein abnormalities were observed in three major categories of renal disease. To explain these abnormalities we turned to studies of protein metabolism utilizing proteins of representative size, namely $L$ chain dimers ( $\lambda$-type) as a representative protein for molecules with a molecular weight less than 50,000 and $\mathrm{IgG}$ as a representative protein for molecules with a molecular weight ranging from 65 to 200,000 .

Ig $G$ and $\lambda-L$ chain metabolism in normal individuals. 10 control individuals with normal renal function metabolized $0.28 \% \pm 0.06 \%$ of the IV IgG pool per hour. All of this metabolism was attributable to endogenous catabolism, i.e., breakdown to constituent amino acids. In contrast, the metabolism of $\lambda$-L chain was 75 -fold more rapid with $22.3 \pm 5 \%$ of the IV pool of this protein metabolized per hour. The major metabolic mechanism, accounting for $99 \%$ of the $\mathrm{L}$ chain metabolism consisted of endogenous catabolism. This corresponded to a fractional catabolic rate of $22.1 \pm 5 \%$ of the intravenous protein pool per hour. A minor metabolic mechanism consisted of loss of intact protein into the urine; this corresponded to a fractional proteinuric rate of $0.17 \pm 0.1 \%$ per $\mathrm{hr}$. The total circulating pool size of $\lambda-\mathrm{L}$ chain in normal individuals was $0.93 \mathrm{mg} / \mathrm{kg}$ and the synthetic rate of free $\lambda$-L chain was $0.21 \pm 0.1 \mathrm{mg} / \mathrm{kg}$ per $\mathrm{hr}$.

Since the $L$ chain excreted in the urine of normal individuals has been shown to be an anabolic product (38, 39 ), the $\lambda$-L chain metabolic turnover data can be used to estimate the rate of synthesis of free $\lambda-L$ chains (i.e., $\lambda-\mathrm{L}$ chains synthesized but not incorporated into intact

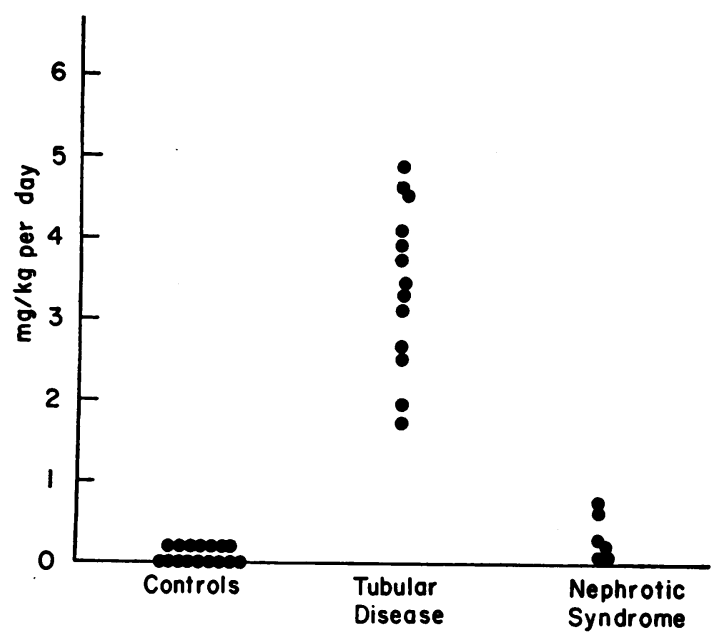

FIGURE 4 Rate of urinary $\lambda$-L chain excretion of control individuals and patients with renal disease.

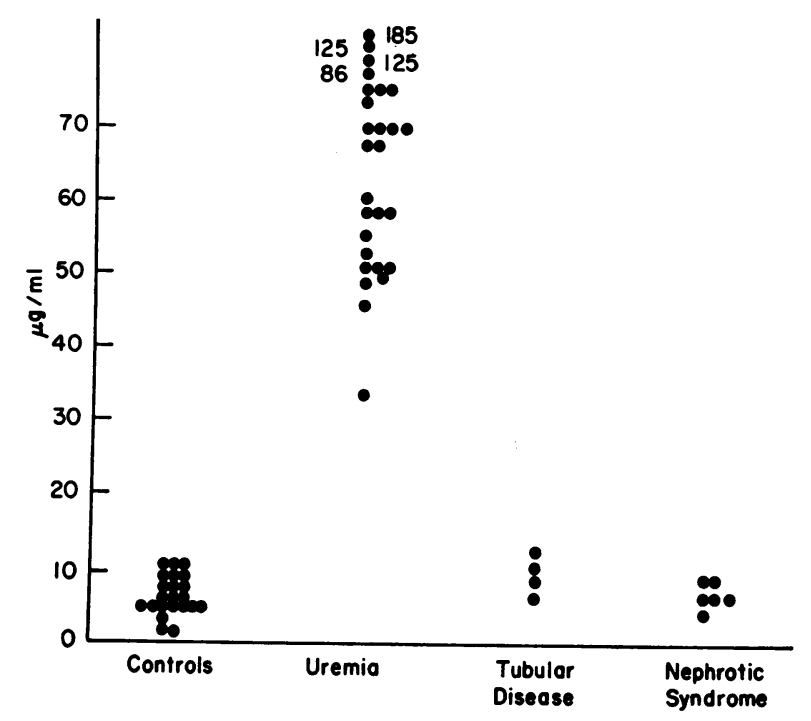

Figure 5 Serum lysozyme concentration of control individuals and patients with renal disease.

immunoglobulins) in an intact organism as compared with the rate of synthesis of $\lambda$-L chains that are incorporated into complete immunoglobulin molecules of one of the five major immunoglobulin classes. The rate of $\lambda$ - $L$ chain synthesis destined for incorporation into intact molecules can be calculated from the product of the following parameters: the rate of synthesis of each immunoglobulin class, the fraction of each immunoglobulin molecule that is composed of $\mathrm{L}$ chain, and the fraction of the total $L$ chain in each immunoglobulin class that is of the $\lambda$-type. Estimates for each of these parameters have been reported $(40-43)$ and with their use it can be calculated that in normal individuals $0.3 \mathrm{mg} / \mathrm{kg}$ of $\lambda-L$ chain is synthesized and incorporated into intact immunoglobulin molecules each hour. ${ }^{3}$ As noted earlier, our results indicate that the synthetic rate of free $\mathrm{L}$ chain is $0.2 \mathrm{mg} / \mathrm{kg}$ per $\mathrm{hr}$. Thus only about $60 \%$ of the $\lambda-\mathrm{L}$ chain molecules synthesized by normal individuals are incorporated into complete immunoglobulin molecules while the remaining $40 \%$ are synthesized and released into the serum as free $\lambda$ - $\mathrm{L}$ chain molecules.

Protein metabolism in patients with tubular proteinuria. The total metabolic rate $(0.30 \% / \mathrm{hr})$ and catabolic rate $(0.29 / \mathrm{hr})$ for IgG were normal in the patients with tubular proteinuria. The IgG proteinuric rate was increased slightly to $0.008 \%$ of the intravenous pool per

\footnotetext{
${ }^{3}$ For example $1.37 \mathrm{mg} / \mathrm{kg}$ of IgG is synthesized per hour in normal individuals $(40) ; 28 \%$ of this molecule is composed of $L$ chain and $33 \%$ of this $L$ chain is of the $\lambda$-type (41). Thus $0.13 \mathrm{mg} / \mathrm{kg}$ of $\lambda-\mathrm{L}$ chain is synthesized and incorporated into IgG molecules per hour. Using similar calculations it can be shown that $0.11 \mathrm{mg} / \mathrm{kg}$ of $\lambda-\mathrm{L}$ chain are normally incorporated into $\mathrm{IgA}$ and $0.02 \mathrm{mg} / \mathrm{kg}$ into IgM per hour.
} 

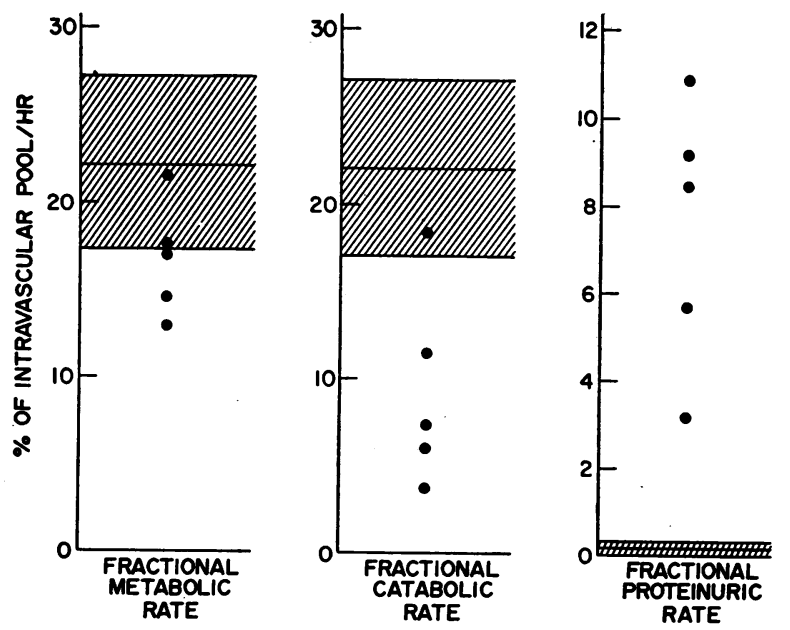

FIgURE 6 Metabolism of $\lambda$ - $\mathrm{L}$ chains in patients with tubular proteinuria.

hour. However, this proteinuria still accounted for less than $3 \%$ of the over-all metabolism of IgG.

In contrast, the metabolism of $\lambda$-L chains in the five patients with tubular proteinuria studied differed considerably from that of normal individuals (Fig. 6). The rate of $\lambda$-L chain synthesis $(0.28 \mathrm{mg} / \mathrm{kg}$ per $\mathrm{hr})$ and the survival of labeled $\lambda-\mathrm{L}$ chain in the serum were normal. The total metabolic rate of $\lambda$-L chain was normal for the three patients with normal creatinine clearance values and slightly decreased for the two patients with reduced clearances of creatinine. The mean total metabolic rate for all five patients was $16.8 \pm 3 \%$ per $\mathrm{hr}$ of the IV pool per hour which does not differ significantly from the normal value of $22.3 \pm 5 \%$ per $\mathrm{hr}(P>0.1)$. However, this normal total metabolic rate was associated with a
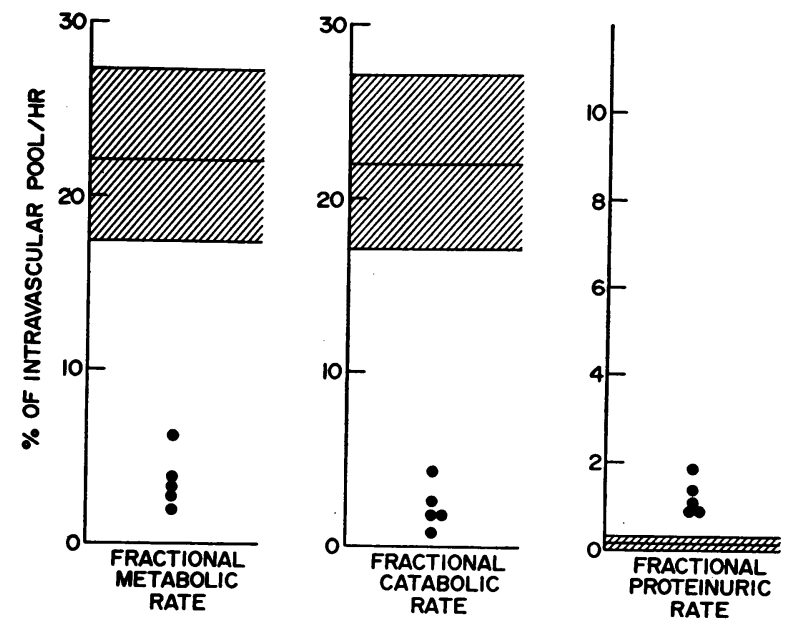

Figure 7 Metabolism of $\lambda$ - $\mathrm{L}$ chain in patients with uremia and end-stage renal disease. 40-fold increase in the fractional proteinuric rate and a corresponding decrease in the fractional catabolic rate. Thus, the fraction of the intravenous pool of $\lambda-L$ chain excreted in the urine was increased from a normal mean of $0.17 \pm 0.1 \%$ of the $\lambda-\mathrm{L}$ chain per hour to $7.4 \pm 2.6 \%$ of the intravenous pool per hour while the fractional catabolic rate was decreased from $22.1 \pm 5 \%$ per hr to $9.5 \pm$ $5.1 \%$ per hr. Thus, it appears that the protein component of tubular proteinuria results from a shift in the pathway of metabolism of small molecules so that proteins which are normally broken down endogenously are excreted into the urine instead. As discussed below, this appears to result from a failure of the proximal tubule of the kidney to take up and catabolize small proteins normally filtered through the glomerulus.

IgG and $\lambda-L$ chain metabolism in patients with glomerular damage and the nephrotic syndrome. The fractional metabolic and catabolic rates for $\lambda$-L chain were normal in those patients with the nephrotic syndrome and normal creatinine clearance values and slightly decreased in those patients with reduced creatinine clearance values. The fractional proteinuric rate for $\lambda-\mathrm{L}$ chain was only slightly increased (mean $0.7 \%$ of IV pool/hr) and proteinuria still accounted for less than $5 \%$ of the over-all metabolism of $\lambda$-L chain. In contrast, the survival of IgG was markedly decreased and the fractional metabolic rate markedly increased to $0.8 \pm 0.09 \%$ of the intravenous pool per hour compared with the $0.28 \pm 0.06 \% / \mathrm{hr}$ value found in control individuals. The major factor in the increased metabolic rate of IgG was the marked increase in the fractional proteinuric rate to $0.44 \pm 0.07 \%$ of the intravenous pool per hour. There was, in addition, a slight increase in the fractional catabolic rate of IgG to $0.36 \pm$ $0.03 \% / \mathrm{hr}$ as compared with the normal value of $0.28 \pm$ $0.06 \% / \mathrm{hr}$. The metabolism of a representative large serum protein, IgM, was studied in four patients with the nephrotic syndrome and was found to be normal. Moreover, the fractional proteinuric rate for $\operatorname{IgM}$ in these individuals was negligible. Thus, the protein metabolic defect in patients with the nephrotic syndrome may be characterized as an abnormal glomerular permeability to proteins of intermediate size leading to an increased fractional proteinuric rate for these proteins.

$I g G$ and $\lambda-L$ chain metabolism in patients with uremia and end-stage renal disease. The metabolic parameters of IgG were normal in patients with uremia. In contrast, the fractional metabolic rate for $\lambda$ - $\mathrm{L}$ chain was reduced to $2.9 \pm 0.7 \%$ per $\mathrm{hr}$ from the normal mean of $22.3 \pm 5 \%$ per hr (Fig. 7). The fractional proteinuric rate was increased slightly to a mean of $1.1 \pm 0.2 \%$ per $\mathrm{hr}$ whereas the fractional catabolic rate was reduced over 10 -fold to $1.8 \pm 0.6 \%$ per hr as compared with a mean of $22.1 \pm 5 \%$ per $\mathrm{hr}$ in control individuals. Thus, the chief change in the metabolic fate of $\lambda-\mathrm{L}$ chain in patients with uremia 


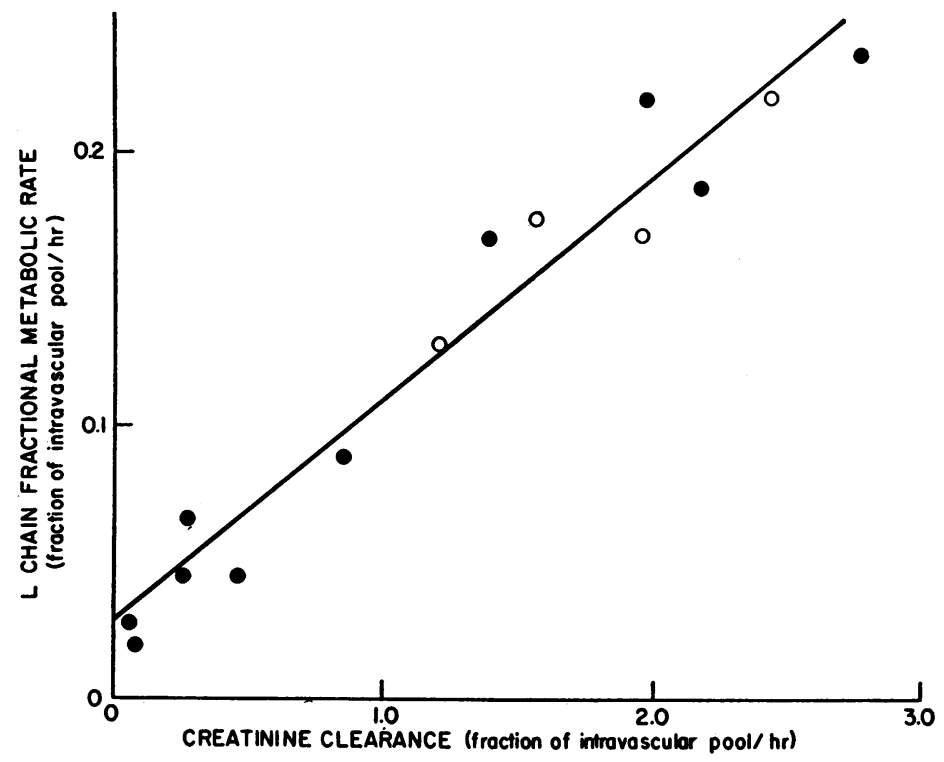

FIGURE 8 Relationship between fractional metabolic rate of $\lambda$-L chain (total loss resulting from both metabolism and proteinuria) and creatinine clearance. Each point represents the value obtained in a separate individual. Patients with tubular proteinuria are indicated by open circles and patients without tubular proteinuria by closed circles. Linear relationships is defined by the regression lines : $y=0.081 x+$ 0.028 .

was a change in the endogenous fractional catabolic rate of this protein.

The rate of $\lambda$-L chain synthesis in patients with uremia was $0.22 \mathrm{mg} / \mathrm{kg}$ per $\mathrm{hr}$ which was quite comparable to that seen in control individuals. Thus, the elevated serum concentration and increased circulating pool of $\lambda-\mathrm{L}$ chain $(7.6 \mathrm{mg} / \mathrm{kg})$ and, presumably, of other low molecular weight serum proteins, in patients with uremia are due solely to their prolonged survival and reduced fractional metabolic rates and not to an increase in the rates of synthesis of these molecules.

\section{DISCUSSION}

Renal control of serum protein metabolism is a complex phenomenon involving a number of separate renal activities. The results of the present study taken together with data reported previously permits us to define the role of the normal kidney in the handling of various classes of serum proteins and provides a coherent view of the pathophysiology of different forms of proteinuria in patients wtih renal disease.

One of the major functions of the kidney is that of the glomerulus acting as a molecular sieve to retain the intermediate and large proteins that predominate in the serum. This function has been most clearly established by clearance experiments using uncharged, metabolically inert macromolecules of graded molecular size such as polyvinylpyrrolidone and dextran which are neither se- creted nor absorbed by the tubules (44-47). Macromolecules with molecular weights of 7000 or less have clearance values equal to that of inulin whereas the glomerular clearances of larger molecules decrease progressively as the molecular weight and molecular radius increases. At the other end of the scale, the glomerular membrane is nearly impermeable to molecules with a molecular weight greater than 60,000 . When there is significant damage the permeability of the membrane to inert macromolecules of intermediate size ( $\mathrm{mol} \mathrm{wt} \mathrm{50-}$ $160,000)$ increases markedly. In contrast, the glomerular filtration of small inert macromolecules does not increase and may even decrease significantly (44).

While clearance studies with inert macromolecules do define many properties of the glomerular membrane they do not necessarily bear directly upon the way in which the kidney handles specific serum proteins since these proteins are metabolically active, charged molecules. Simple clearance studies similar to those with inert macromolecules are not satisfactory for the measurement of glomerular permeability of serum proteins since protein appearance in the urine (and therefore measurements of "clearance") will be a function of both glomerular permeability of these proteins and other renal mechanisms including tubular uptake.

Another method of measuring glomerular permeability of protein other than through total renal clearance determinations is suggested by the present studies. This 
method takes advantage of the fact that the glomerular clearance rate of a serum protein can be related to the total metabolic rate of that protein by the following relationship: glomerular clearance rate $=$ total metabolic rate - nonrenal catabolic rate (provided there is no reabsorption of the protein back into the blood, an assumption which is supported by certain evidence presented below). The total metabolic rate of any protein is measured by the turnover technique. The nonrenal catabolic rate is obtained as follows: the total metabolic rate of a protein is plotted against the creatinine clearance (expressed as a fraction of the plasma creatinine pool cleared per unit time) for a number of individuals having a range of creatinine clearance values. The plot obtained for $\lambda$-L chain is shown in Fig. 8, each point representing the value obtained in a separate individual. It can be seen that a linear relationship is obtained that is defined by the regression line: $y=0.081 x+0.028$, where $y$ is the fractional metabolic rate of $\lambda$-L chain and $x$ is the fractional creatinine clearance rate. The nonrenal metabolic rate for $\lambda$ - $\mathrm{L}$ chains is defined by the ordinate intercept of this regression line, i.e., the metabolic rate at zero creatinine clearance when the nephron population is negligible. Subtraction of this value from the total $\lambda$-L chain fractional metabolic rate of any given patient yields an estimate for the glomerular $\lambda-\mathrm{L}$ chain clearance rate for that patient (expressed as a fraction of the circulating $\lambda-\mathrm{L}$ chain pool cleared per unit time). Another parameter of the glomerular permeability of a protein, the clearance of the protein relative to that of creatinine or the sieving coefficient, is defined by the slope of the regression line. In the present case, $\lambda-\mathrm{L}$ chain dimers appear to have $7-9 \%$ of the glomerular permeability of creatinine. This value agrees well with that predicted from the glomerular permeability values obtained for inert macromolecules having a comparable size (45-47).

A second level of renal participation in serum protein metabolism comes into play after passage of protein through the glomerular sieve and exposure of protein to tubular cells. At this point, protein in the tubular lumen may be taken up by tubular cells or may pass into the urine. The magnitude of the uptake can be estimated from a knowledge of the amount of protein filtered and the amount actually excreted into the urine. From the present studies the amount of $\lambda-\mathrm{L}$ chain filtered through the glomerulus may be estimated from the sieving coefficient, the circulating $\lambda$-L chain pool, and the glomerular filtration rate. Using these parameters we estimate that on the order of $5 \mathrm{mg}$ of $\lambda-\mathrm{L}$ chain protein per $\mathrm{kg}$ of body weight is filtered by normal individuals daily. Since only $0.04 \mathrm{mg} / \mathrm{kg}$ is excreted each day, it is clear that over $99 \%$ of the filtered protein is taken up by the tubular cells. Other proteins may have a different fractional uptake by the tubular cells since, as discussed below, there is evidence suggesting that the uptake process may be selective.

Proteins taken up by the tubular cells may theoretically be returned to the circulation or catabolized within the cells. The data in the present studies suggest that catabolism within the cells is the dominant process and that there is little transport of intact $\mathrm{L}$ chain through the cell back into the blood stream. This conclusion is drawn from the fact that the total $\lambda-\mathrm{L}$ chain metabolic rate of patients with tubular proteinuria (Fig. 8, open circles) falls on the line relating the $\lambda-L$ chain metabolic rate to the creatinine clearance obtained for patients without tubular proteinuria (Fig. 8, closed circles). If transtubular transport of intact $\lambda$-L chain were a significant process, the points representing patients with tubular proteinuria (open circles) would be significantly above the line determined by the points representing patients without tubular proteinuria. This would result from the urinary loss of proteins which are normally reabsorbed and returned to circulation. Thus, the finding of total metabolic rates for patients with tubular proteinuria that are comparable to those of patients without tubular disease but with comparable creatinine clearance values is in accord with the conclusion that there is little transport of intact $\lambda$-L chains from the tubular lumen to the blood stream. This conclusion is the same as that drawn from studies using the renal tubular toxin sodium maleate to produce tubular proteinuria. In this case a normal total metabolic rate for $\mathrm{L}$ chain was observed despite disruption of tubular function and increased urinary excretion of L chain (24). Radioautographic studies of the kidney after intravenous administration of labeled albumin or other serum proteins also suggest that transport of these proteins from the tubular lumen to the blood stream is not a major function of the kidney (48).

These considerations bring into focus the role of the kidney in the endogenous catabolism of serum proteins. As shown in the present studies as well as work in normal animals and man the primary metabolic fate of such small proteins as lysozyme, ribonuclease, Bence Jones proteins, and $\mathrm{L}$ chains of the immunoglobulins is breakdown to their constituent amino acids rather than excretion intact into the urine $(19,20,23,24,49)$. In the present study as well as in that of Jensen (49) from 95 to $99 \%$ of the rate of $\mathrm{L}$ chain metabolism in normal individuals is accounted for by catabolism. That the kidney is the primary site of this catabolism was first suggested in our previous studies in which impaired renal function in man was associated with reduced $L$ chain and Bence Jones protein catabolism (19). More direct studies of $\mathrm{L}$ chain metabolism in nephrectomized and ureter severed mice led to the identification of the kidney as the organ site of L chain metabolism (20) as well as the catabolism of $\beta_{2}$ microglobulin (22) and such enzymes 
as ribonuclease and lysozyme." The present studies of $\lambda$-L chain metabolism reaffirm the importance of the kidney in the catabolism of small proteins. It was shown that extrarenal catabolism defined by the ordinate intercept of the line relating the total $\lambda$-L chain metabolic rate and the creatinine clearance (Fig. 8) was approximately $10 \%$ of the over-all catabolism of $\lambda$-L chain molecules. Thus $90 \%$ of the catabolism of $\lambda-L$ chain occurs in the kidney. The catabolic site within the kidney appears to be the tubular cell. This has been shown in morphological studies using enzyme markers (50-53) as well as metabolic studies of renal degradative function after the administration of sodium maleate (24).

In summary, normal kidney function with regard to the metabolism of small and large serum proteins may be characterized as follows: the small serum proteins such as $\lambda$ - $L$ chain have a variable glomerular permeability (depending on molecular radius) and are taken up by the tubular cells where they undergo catabolism. For these proteins of high glomerular permeability the kidney tubule is the major catabolic site. In contrast, larger serum proteins, exemplified by IgG are retained by the glomerulus, do not reach the tubular catabolic site and are not catabolized in the kidney under normal conditions. The abnormalities of urinary protein excretion seen in patients with tubular proteinuria with the nephrotic syndrome and with uremia can be understood in terms of derangements of the two major functions of the kidney, the retention of proteins by the glomerulus and the catabolism of small filterable proteins by the proximal convoluted tubule.

Tubular disease. Patients with proximal tubular lesions have been shown to excrete a heterogenous group of low molecular weight proteins into the urine (1-13). It has been demonstrated that most if not all of these proteins originate in the serum and are present in normal urine in minute amounts (6). Harrison, Lunt, Scott, and Blainey (5) using measurements of serum and urinary concentrations of specific low molecular weight proteins (e.g., lysozyme and ribonuclease) have shown that patients with tubular proteinuria have elevated excretion rates of such proteins.

In the present study the pathophysiological mechanisms responsible for the proteinuria of patients with tubular disorders was studied by turnover studies using a small protein, $\lambda$-L chain. Patients with tubular proteinuria had normal rates of $\lambda-\mathrm{L}$ chain synthesis, normal survivals of the $\lambda-\mathrm{L}$ chain in the serum, and correspondingly normal total metabolic rates. Similarly, the glomerular permeability for $\lambda$-L chain, that is, the sieving coefficient for this protein, was the same in patients with tubular disorders and controls. This latter finding is in accordance

\footnotetext{
* Mogielnicki, R. P., W. Strober, and T. A. Waldmann. Unpublished observations.
}

with the observation of Hulme (54) who reported a normal polyvinylpyrrolidone clearance in a patient with tubular disease.

These normal metabolic parameters in patients with tubular disease occurred in association with a vastly increased fractional proteinuric rate and a correspondingly decreased fractional catabolic rate. It is therefore apparent that the tubular proteinuria seen in patients with pure tubular disease is due to the failure of the proximal tubule of the kidney to take up and catabolize small proteins that are normally filtered through the glomerulus. However, since the normal route of low molecular weight protein disposal, tubular catabolism, is counterbalanced by urinary excretion of intact protein, the over-all rate of metabolism remains unchanged and no protein accumulates in the circulation.

On the basis of this pathophysiologic mechanism it can be predicted that patients with tubular proteinuria would have a marked increase in the urinary excretion of many proteins in the serum that are small enough to pass through the glomerulus.

Glomerular disease. Patients with the nephrotic syndrome and glomerular proteinuria have a significant reduction in the serum concentration of proteins of intermediate molecular size such as albumin and IgG, associated with markedly increased concentrations of such proteins in the urine. In the studies reported here and in previous studies $(14,18,55,56)$ the survival of IgG was markedly decreased in such patients due primarily to an increase in the rate of $\operatorname{IgG}$ lost as proteinuria. There was, in addition, a slight increase in the endogenous fractional catabolic rate for IgG presumably due to some degree of renal catabolism of IgG molecules filtered through the glomerulus. It should be noted that the urinary concentration (57-59) and the serum survival of very large proteins such as IgM (mol wt 900,000) was normal in nephrotic patients and that the proteinuric rate for IgM remained negligible. Thus, it appears that in patients with the nephrotic syndrome the glomeruli become abnormally permeable to proteins of intermediate size although the sieving function of the glomerulus is not lost completely and large molecules such as $\operatorname{IgM}$ continue to be retained.

The metabolic parameters for low molecular weight proteins such as $\lambda-\mathrm{L}$ chain remained normal in patients with the nephrotic syndrome or showed a prolongation of $\lambda$-L chain survival in patients with decreased creatinine clearance values. The observation that there is a near normal metabolic rate for $\lambda-\mathrm{L}$ chain and a marked increase in the metabolic rate of IgG is in accord with observations made in studies using inert macromolecules. In these studies patients with the nephrotic syndrome had a markedly increased permeability to inert macromolecules in the 50-200,000 mol wt range with a de- 
creased or normal clearance of low molecular weight macromokcules (44). It is apparent therefore that the pathologic changes in the glomerular membrane do not significantly affect the passage of low molecular weight molecules which normally pass through the membrane with relative ease.

Hardwick and Squire (60) have suggested that the uptake of serum proteins that have entered the tubular lumen is nonselective and comparable for all proteins. Harrison and Blainey (61) have challenged this view when it is applied to low molecular weight proteins since they found normal excretion rates and clearances of low molecular weight proteins in patients who had the nephrotic syndrome and heavy proteinuria. Selective tubular handling of low molecular weight proteins is also suggested by the results of other workers studying urinary excretion patterns of proteins of different molecular weights $(62,63)$. The studies of patients with the nephrotic syndrome reported here are in accord with these latter studies. In nephrotic patients over $95 \%$ of the metabolized $\lambda-\mathrm{L}$ chain is being catabolized, presumably by uptake and breakdown within the proximal convoluted tubular cells at a time when over $50 \%$ of the metabolism of IgG molecules is accounted for by proteinuria. Thus, it appears that there is a preferential tubular uptake of the $\lambda$-L chain molecule as compared to IgG and other proteins of intermediate size.

Uremia and nephron loss disease. The serum concentration of $\lambda-\mathrm{L}$ chain and lysozyme were markedly increased in the patients with uremia who have greatly decreased numbers of functioning nephrons. This could not be explained by an increased rate of $\lambda-\mathrm{L}$ chain synthesis which was normal in these patients, but could be accounted for by prolonged serum $\lambda$-L chain survival which was associated with comparable reductions in fractional metabolic rate and fractional catabolic rate of $\lambda-\mathrm{L}$ chain. Presumably, the reduced fractional catabolic rate of $\lambda-\mathrm{L}$ chain results from the loss of functional renal tissue and entire nephrons. Thus, the $\lambda-L$ chains were not filtered through the glomerulus and were not exposed to their normal catabolic site, the renal tubule, and in addition, were not excreted into the urine in excessive quantities as in tubular proteinuria. The result was the accumulation of $\lambda-\mathrm{L}$ chain in the circulation.

A second and much more minor abnormality seen in patients with uremia was an increased proteinuric rate associated with a markedly increased proteinuric/catabolic ratio. This presumably reflects functional damage of tubules in nephrons where glomerular filtration of protein persists and may explain the fact that acrylamide gel analysis of urine of uremic patients frequently shows a tubular pattern.

The failure of renal metabolism would be expected to cause an elevation in the serum levels of many small pro- teins normally filtered through the glomerulus and indeed we have shown that lysozyme concentrations are elevated in the serum of patients with uremia. This elevation of serum levels would be most marked for those small proteins that do not have significant extrarenal sites of catabolism and that do not have servoregulatory mechanisms that decrease the rate of protein synthesis in the face of an elevated serum concentration. The accumulation of low molecular weight proteins in patients with grossly decreased numbers of functioning nephrons obviously produces widespread exposure of many physiological mechanisms to the actions of biologically active enzymes, hormones, and other proteins which are normally excreted or catabolized within the kidney. This accumulation of biologically active substances may play a role in causing certain manifestation of the uremic syndrome.

\section{ACKNOWLEDGMENTS}

We acknowledge and appreciate the excellent technical assistance of Mrs. Suellan Balestra and Mrs. Margaret C. Jost. We would also like to acknowledge the valuable assistance of Miss Teri Mills in preparation of the manuscript.

\section{REFERENCES}

1. Butler, E. A., and F. V. Flynn. 1958. The proteinuria of renal tubular disorders. Lancet. II : 978.

2. Butler, E. A., F. V. Flynn, H. Harris, and E. B. Robson. 1962. A study of urine proteins by two-dimensional electrophoresis with a special reference to the proteinuria of renal tubular disorders. Clin. Chim. Acta. 7: 34 .

3. Creeth, J. M., R. A. Kekwick, F. V. Flynn, H. Harris, and E. B. Robson. 1963. An ultracentrifuge study of urine proteins with particular reference to the proteinuria of renal tubular disorders. Clin. Chim. Acta. 8: 406.

4. Harrison, J. F., and J. D. Blainey. 1967. Low molecular weight proteinuria in chronic renal disease. Clin. Sci. 33: 381 .

5. Harrison, J. F., G. S. Lunt, P. Scott, and J. D. Blainey. 1968. Urinary lysozyme, ribonuclease and lowmolecular-weight protein in renal disease. Lancet. I: 371.

6. Flynn, F. V., and H. S. Platt. 1968. The origin of the proteins excreted in tubular proteinuria. Clin. Chim. Acta. 21 : 377.

7. Walravens, P., E. C. Laterre, and J. F. Heremans. 1968. Studies on tubular proteinuria. Clin. Chim. Acta. 19: 107.

8. Schultz, H. E., and J. F. Heremans. 1966. Molecular Biology of Human Proteins with Special Reference to Plasma Proteins. Elsevier Publishing Co., Amsterdam. 670.

9. Piscator, M. 1966. Proteinuria in chronic cadmium poisoning. Arch. Environ. Health. 12: 335

10. Berggard, I. 1965. Identification and isolation of urinary proteins. Protides Biol. Fluids Proc. 12th Coll. 285.

11. Butler, E. A., and F. V. Flynn. 1961. The occurrence of post-gamma protein in urine: a new protein abnormality. J. Clin. Pathol. 14: 172. 
12. Revillard, J. P., and Y. Manuel. 1965. Les Protéinures, valeur séméiologique de leur Etude Electrophorétique. Maurice Camugli, Lyon, France.

13. Debray-Sachs, M., and C. Sachs. 1966. Proteinuria in patients with homotransplanted kidneys. Nature (Lond.). 212: 209.

14. Gitlin, D., C. A. Janeway, and L. E. Farr. 1956. Studies on the metabolism of plasma proteins in the nephrotic syndrome. I. Albumin, $\gamma$-globulin and iron binding globulin. J. Clin. Invest. 35: 44.

15. Sellers, A. L., J. Katz, and S. Rosenfeld. 1961. Plasma albumin catabolism in experimental nephrosis. Nature (Lond.). 192: 562.

16. Rosenfeld, S., J. Katz, and A. L. Sellers. 1962. Effects of nephrectomy on $I^{131}$ albumin turnover in the dog. J. Lab. Clin. Med. 59: 381.

17. Katz, J., S. Rosenfeld, and A. L. Sellers. 1960. Role of the kidney in plasma albumin catabolism. Am. J. Physiol. 198 : 814.

18. Jensen, H. 1969. Plasma protein metabolism in the nephrotic syndrome. Munksgaard, A/S, Copenhagen. 15.

19. Solomon, A. T. A. Waldmann, J. L. Fahey, and A. S. McFarlane. 1964. Metabolism of Bence-Jones proteins. J. Clin. Invest. 43: 103.

20. Wochner, R. D., W. Strober, and T. A. Waldmann. 1967. The role of the kidney in the catabolism of Bence Jones proteins and immunoglobulin fragments. J. Exp. Med. 126: 207.

21. Chamberlain, M. J., and L. Stimmler. 1967. The renal handling of insulin. J. Clin. Invest. 46: 911.

22. Bernier, G. M., and M. E. Conrad. 1969. Catabolism of human $\beta_{2}$-microglobulin by the rat kidney. Am. J. Physiol. 217: 1359.

23. Jensen, K. 1970. Metabolism of Bence Jones proteins in multiple myeloma patients and in patients with renal disease. Scand. J. Clin. Lab. Invest. 26: 13.

24. Mogielnicki, R. P., T. A. Waldmann, and W. Strober. 1971. The renal handling of low molecular weight proteins. I. L-chain metabolism in experimental renal disease. J. Clin. Invest. 50: 901.

25. Davis, B. J. 1964. Disc electrophoresis II : methods and application to human serum proteins. Ann. N. Y. Acad. Sci. 121 : 404.

26. Shapiro, A. L., E. Vinuela, and J. V. Maizel, Jr. 1967. Molecular weight estimation of polypeptide chains by electrophoresis in SDS-polyacrylamide gels. Biochem. Biophys. Res. Commun. 28: 815.

27. Gornall, A. G., C. J. Bardawill, and M. M. David. 1949. Determination of serum proteins by means of the biuret reaction. J. Biol. Chem. 177: 751 .

28. Osserman, E. F., and D. P. Lawlor. 1966. Serum and urinary lysozyme (Muramidase) in monocytic and monomyelocytic leukemia. J. Exp. Med. 124: 921.

29. Mann, D., H. Granger, and J. L. Fahey. 1969. Use of insoluble antibody for quantitative determination of small amounts of immunoglobulin. J. Immunol. 102: 618.

30. Hunter, W. M., and F. C. Greenwood. 1962. Preparation of iodine-131 labeled human growth hormone of high specific activity. Nature (Lond.). 194: 495.

31. Mancini, G., A. O. Carbonara, and J. F. Heremans. 1965. Immunochemical quantitation of antigens by single radial immunodiffusion. Immunochemistry. 2: 235.

32. McFarlane, A. S. 1958. Effective trace-labelling of proteins with iodine. Nature (Lond.). 182: 53.
33. Andrews, H. L., D. C. Peterson, R. E. Murphy, and E. J. Myers. 1965. An organic plastic, localizing wholebody counter. J. Nucl. Med. 6: 78 .

34. Nosslin, B. 1966. Applications of tracer theory to protein turnover studies. J. Nucl. Biol. Med. 10: 3 .

35. Berman, M., E. Shahn, and M. F. Weiss. 1962. The routine fitting of kinetic data to models: a mathematical formalism for digital computers. Biophys. J. 2: 275.

36. Berman, M. 1965. Compartmental analysis in kinetics. In Computers in Biomedical Research, R. Stacy and B. Waxman, editors. Academic Press, Inc., New York. 2: 173 .

37. Berman, M., and M. F. Weiss. 1967. Users' Manual for SAAM. U. S. Public Health Service Publication No. 1703. U. S. Department of Health, Education and Welfare. U. S. Government Printing Office. Washington, D. C.

38. Gordon, D. A., A. Z. Eisen, and J. H. Vaughan. 1963. Serum and urinary gamma globulin in rheumatoid arthritis. Trans. Am. Assoc. Physicians (Phila.). 76: 222.

39. Gordon, D. A., A. Z. Eisen, and J. H. Vaughan. 1966. Studies on urinary gamma globulins in patients with rheumatoid arthritis. Arthritis Rheum. 9: 575 .

40. Waldmann, T. A., and W. Strober. 1969. Metabolism of immunoglobulins. Prog. Allergy. 13: 1.

41. Terry, W. D., J. L. Fahey, and A. G. Steinberg. 1965. GM and INV factors in subclasses of human IgG. $J$. Exp. Med. 122: 1087.

42. Wollheim, T. A., and J. Snigurowicz. 1967. Studies on the macroglobulins of human serum IV: the frequency of light chain types $\kappa$ and $\lambda$ in polyclonal and monoclonal $\gamma \mathrm{M}$. Scand. J. Haematol. 4: 111.

43. Vaerman, J. P., J. F. Heremans, and C. B. Laurell. 1968. Distribution of $\alpha$-chain subclasses in normal and pathological IgA-globulins. Immunology. 14: 425.

44. Hulme, B., and J. Hardwicke. 1968. Human glomerular permeability to macromolecules in health and disease. Clin. Sci. $34: 515$.

45. Brewer, D. B. 1951. Renal clearances of dextrans of varying molecular weights. Proc. Roy. Soc. Med. 44: 561.

46. Wallenius, G. 1954. Renal clearance of dextran as a measure of glomerular permeability. Acta Soc. Med. Ups. Suppl. 4: 1 .

47. Arturson, G., and G. Wallenius. 1964. The renal clearance of dextran of different molecular sizes in normal humans. Scand. J. Clin. Lab. Invest. 16: 81.

48. Maunsbach, A. B. 1966. Absorption of $I^{120}$-labeled homologous albumin by rat kidney proximal tubule cells. J. Ultrastruct. Res. 15 : 197.

49. Jensen, K. 1970. Metabolism of Bence Jones proteins in non-myeloma patients with normal renal function Scand. J. Clin. Lab. Invest. 25 : 281.

50. Oliver, J., M. MacDowell, and Y. C. Lee. 1954. Cellular mechanisms of protein metabolism in the nephron. I. The structural aspects of proteinuria; tubular absorption; droplet formation and the disposal of proteins. J. Exp. Med. $99: 589$.

51. Lathem, W., B. B. Davis, P. H. Zweig, and R. Dew. 1960. The demonstration and localization of renal tubular reabsorption of hemoglobin by stop flow analysis. J. Clin. Invest. 39: 840.

52. Straus, W. 1961. Cytochemical observations on the transport of intravenously injected horseradish peroxi- 
dase and the development of phagosomes in the cells of the kidney of the rat. Exp. Cell. Res. 22: 282.

53. Miller, F., and G. E. Palade. 1964. Lytic activities in renal protein absorption droplets. J. Cell. Biol. 23: 519.

54. Hulme, B. 1968. M. D. Thesis, University of Burmingham. Quoted in: Hardwicke, J. 1970. Proteinuria. Sci. Basis Med. Annu. Rev. 211.

55. Andersen, S. B. 1963. Metabolism of gamma s: globulin in secondary hypogammaglobulinemia. Am. J. Med. 35: 708.

56. Birke, G., S. O. Liljedahl, B. Olhagen, L. O. Plantin, and S. Ahlinder. 1963. Catabolism and distribution of gammaglobulin. A preliminary study with I-labelled gammaglobulin. Acta Med. Scand. 173: 589.

57. Blainey, J. B., D. B. Brewer, J. Hardwicke, and J. F. Soothill. 1960. The nephrotic syndrome: diagnosis by renal biopsy and biochemical and immunological analyses related to the response to steroid therapy. $Q$. $J$. Med. $29: 235$.
58. Joachim, G. R., J. S. Cameron, M. Schwartz, and E. L. Becker. 1964. Selectivity of protein excretion in patients with the nephrotic syndrome. J. Clin. Invest. 43: 2332.

59. Barth, W. F., R. D. Wochner, T. A. Waldmann, and J. L. Fahey. 1964. Metabolism of human gamma macroglobulins. J. Clin. Invest. 43: 1048.

60. Hardwicke, J., and J. R. Squire. 1955. The relationship between plasma albumin concentration and protein excretion in patients with proteinuria. Clin. Sci. 14: 509.

61. Harrison, J. F., and J. D. Blainey. 1967. Low molecular weight proteinuria in chronic renal disease. Clin. Sci. $33: 381$.

62. Bienenstock, J., and J. Poortmans. 1970. Renal clearance of 15 plasma proteins in renal disease. J. Lab. Clin. Med. 75: 297.

63. Dillard, M. G., A. J. Pesce, V. E. Pollak, and I. Boreisha. 1971. Proteinuria and renal protein clearances in patients with renal tubular disorders. J. Lab. Clin. Med. 78: 203. 